\title{
Gambaran Konsep Diri Orang dengan HIV AIDS (ODHA) di RSUD Kabupaten Indramayu
}

\author{
Bestina Nindy Virgiani ${ }^{1}$
}

${ }_{1}^{1}$ STIKes Indramayu, email: ns.bestina08@gmail.com

\section{ABSTRACT}

The self-concept of PLHIV is a decisive factor in interpersonal communication, because everyone behaves as much as possible according to his concept. The results of interviews with 10 PLWHA showed that the respondents still felt ashamed and felt that they were not useful for this life and felt excluded by their family and environment. The purpose of the study is to describe the concept of self (PLWHA). The design used in this study is quantitative with a descriptive approach. The sampling method uses accidental sampling as many as 188 respondents. The data collection tool uses a questionnaire. The results showed 113 respondents (60.1\%) had a positive self-concept. 98 respondents (52.1\%) had a positive body image, 116 respondents (61.7\%) had an ideal positive self, 96 respondents (51.1\%) had negative self-esteem, 167 respondents (83.5\%) had an appearance negative role and 98 respondents (52.1\%) had a positive self-identity. Conclusion in this study more than half the number of respondents have a positive selfconcept, the respondent has accepted what happened to him and is ready to face life in the future and considers that life is a process of discovery.

Keywords: PLWHA, self concept. 


\section{ABSTRAK}

Konsep diri ODHA merupakan faktor yang menentukan dalam komunikasi antar pribadi, karena setiap orang bertingkah laku sedapat mungkin sesuai dengan konsep dirinya. Hasil wawancara dengan 10 ODHA diperoleh hasil bahwa responden masih merasa malu dan merasa bahwa dirinya tidak berguna untuk kehidupan ini serta merasa dikucilkan oleh keluarga dan lingkungan sekitar. Tujuan penelitian untuk mengetahui gambaran konsep diri (ODHA). Desain yang digunakan dalam penelitian ini adalah kuantitatif dengan pendekatan deskriptif. Metode sampling menggunakan accidental sampling sebanyak 188 Responden. Alat pengumpulan data menggunakan kuesioner. Hasil penelitian didapatkan 113 responden $(60,1 \%)$ memiliki konsep diri positif. sebanyak 98 responden $(52,1 \%)$ memiliki citra tubuh positif, 116 responden $(61,7 \%)$ memiliki ideal diri positif, 96 responden $(51,1 \%)$ memiliki harga diri negatif, 167 responden $(83,5 \%)$ memiliki penampilan peran negatif dan 98 responden $(52,1 \%)$ memiliki identitas diri positif. Simpulan pada penelitian ini lebih dari setengah jumlah responden memiliki konsep diri positif, responden sudah menerima apa yang terjadi pada dirinya dan siap menghadapi kehidupan kedepannya serta menganggap bahwa hidup adalah proses penemuan.

Kata kunci : ODHA, Konsep diri. 
Pendahuluan

Di indonesia jumlah kasus HIV yang dilaporkan dari tahun 2005 sampai dengan tahun Desember 2017 sebanyak 280.623. Sedangkan kasus AIDS dari tahun 2005 sampai dengan tahun 2017 relatif stabil setiap tahunnya. Jumlah kumulatif HIV AIDS dari tahun $1987 \quad$ sampai dengan Desember 2017 sebanyak $\quad 102.667$ orang. Dari tahun 2005 sampai dengan tahun 2017 (Kemenkes RI, 2017).

Jawa

Barat

merupakan Provinsi dengan kasus HIV AIDS terbanyak ke-4 di Indonesia. Kasus HIV di Jawa Barat mencapai 28.964 dan AIDS mencapai 6.502 kasus. Sedangkan di kabupaten Indramayu sendiri merupakan Kabupaten dengan kasus HIV AIDS tertinggi ke-3 di Jawa Barat. Berdasarkan data dari Dinas Kesehatan
Kabupaten Indramayu kasus HIV AIDS di Indramayu dari tahun 1993 sampai dengan bulan Juni 2017 sebanyak 2.737 orang, dengan jumlah terbanyak pada kelompok umur 20-39 tahun.

Penyakit HIV AIDS tidak

hanya meningkatkan angka kesakitan tetapi juga angka kematian. Angka kematian yang diakibatkan oleh penyakit HIV AIDS di seluruh dunia mencapai 1,5 juta yang terdiri dari 1,3 juta dewasa dan 190.000 terjadi pada anak berusia $<15$ tahun. Di Indonesia angka kematian akibat HIV AIDS sedikit mengalami peningkatan dari $1,07 \%$ pada tahun 2015 menjadi 1, 08\% pada bulan Desember 2017. (Kemenkes RI, 2017). HIV

AIDS menimbulkan beberapa dampak penderitanya bagi secara fisik, sosial 
maupun psikologis.

Dampak fisik dari HIV AIDS meliputi penurunan berat badan berlebihan, perubahan penampilan, penurunan berat badan, gangguan kulit dan mudah lesu (Adji, 2007). Dampak sosial dari HIV AIDS seperti stigmatisasi, diskriminasi, isolasi sosial, serta tindakan kekerasan ODHA. terhadap dampak dapat Sedangkan psikologis menyebabkan penderita merasa waktu kematiannya sudah dekat, sehingga mengakibatkan ODHA mengalami stres, keyakinan diri yang rendah, sering mengalami kecemasan serta mengalami perubahan pada konsep diri. (Pardita. 2014). Kondisi tersebut dapat menghambat aktivitas dan perkembangan ODHA sehingga kehidupan efektif sehari-harinya terganggu.
Menurut Hurlock dalam Ghufron (2011) konsep diri merupakan gambaran seseorang mengenai diri sendiri yang gabungan dari keyakinan fisik, psikologis, sosial, emosional aspirasi dan prestasi yang mereka capai. Konsep diri ODHA merupakan faktor yang menentukan dalam komunikasi antar pribadi, karena setiap orang bertingkah laku sedapat mungkin sesuai dengan konsep dirinya (Djuanda, 2009).

Konsep diri terbagi menjadi dua bagian yaitu konsep diri positif dan konsep diri negatif. Konsep diri positif merupakan pemahaman dan penerimaan diri terhadap sejumlah fakta yang bermacam-macam sehubungan dengan diri. Sedangkan konsep diri negatif, di satu sisi dikarakteristikan dengan pandangan yang tidak stabil sehubungan dengan diri, yaitu 
individu

tidak mengetahui secara pasti mengenai kekuatan, kelemahan, dan hal-hal yang dapat dihargai dalam hidupnya.

ODHA yang memiliki konsep diri negatif menyakini

memandang dan dirinya lemah, tidak berdaya, tidak dapat berbuat apa-apa, tidak kompeten, gagal, malang, tidak menarik, tidak disukai dan kehilangan daya tarik terhadap hidup. Orang dengan konsep diri negatif, akan mudah menyerah sebelum berperang dan jika gagal, akan ada dua pihak yang disalahkan, entah itu menyalahkan diri sendiri (secara negatif) atau menyalahkan orang lain. Akibat dari ODHA yang memiliki konsep diri negatif antara lain, menolak pengobatan, tidak patuh terhadap pengobatan Anti Retro Virus (ARV), menarik diri dari lingkungan, berkeinginan bunuh diri dan merasa tidak berharga (Rini, 2002).

Berdasarkan hasil studi pendahuluan yang dilakukan pada tanggal 4 April 2018 melalui wawancara dengan 10 ODHA di Klinik Mawar RSUD Kabupaten Indramayu diperoleh hasil bahwa 3 responden mengatakan malu akan dirinya, 4 responden mengatakan merasa dikucilkan oleh keluarga dan lingkungan sekitar dan 3 responden menyatakan bahwa dirinya tidak berguna untuk kehidupan.

Berdasarkan latar belakang tersebut, maka peneliti tertarik melakukan penelitian tentang "Gambaran konsep diri orang dengan HIV AIDS (ODHA) di RSUD Kabupaten Indramayu".

\section{Metode}

Desain yang digunakan dalam penelitian ini adalah kuantitatif dengan pendekatan 
Bestina Nindy Virgiani: Konsep Diri (ODHA)

deskriptif. Populasi dalam penelitian ini semua ODHA di Klinik Mawar RSUD Kabupaten Indramayu. Teknik pengambilan sampel pada penelitian ini dengan accidental sampling menggunakan rumus $Z$ sebanyak 188 responden. Alat pengumpulan data pada penelitian ini adalah menggunakan

kuesioner. Analisa data dalam penelitian ini adalah Analisis Univariat (analisis deskriptif). Tempat penelitian telah dilaksanakan di Klinik Mawar Rumah Sakit Umum Daerah Kabupaten Indramayu pada tanggal 19-26 Juli 2018.

Hasil Penelitian

1. Karakteristik Responden

\section{a. Umur}

Tabel 1. Distribusi Responden

Berdasarkan Umur di Klinik Mawar RSUD Kabupaten Indramayu Tahun 2018

\begin{tabular}{ccccccc}
\hline Variabel & $\mathbf{n}$ & Mean & Med & S.D & $\begin{array}{c}\text { Min- } \\
\text { Max }\end{array}$ & 95\% CI \\
\hline Umur & 18 & 35,54 & 36,0 & 3,59 & $21-$ & $35,03-$ \\
& 9 & & 0 & & 44 & 36,06 \\
\hline
\end{tabular}

Berdasarkan tabel 1 diatas menunjukan bahwa rata-rata umur responden adalah 35.54 tahun, standar deviasi 3,587. Umur tertua 44 dan umur termuda 21 . Hasil estimasi interval dapat disimpulkan bahwa 95\% diyakini bahwa rata-rata umur orang dengan gangguan HIV AIDS adalah antara 35.03 sampai dengan 36.06 tahun.

b. Jenis Kelamin

Tabel 2 Distribusi

Responden

Berdasarkan Jenis

Kelamin di Klinik

Mawar RSUD

Kabupaten

Indramayu Tahun 2018

\begin{tabular}{lccc}
\hline \multicolumn{1}{c}{ Variabel } & Kategori & F & \% \\
\hline Jenis & Laki-Laki & 84 & 45 \\
Kelamin & & & \\
\cline { 2 - 4 } & Perempuan & 104 & 55 \\
\hline Jumlah & & 188 & 100 \\
\hline
\end{tabular}

Berdasarkan tabel 2 di atas menunjukan 
Bestina Nindy Virgiani: Konsep Diri (ODHA)

bahwa sebanyak 104 responden berjenis $(55,0 \%)$ perempuan.

c. Tingkat Pendidikan

Tabel 3 Distribusi

Responden

Berdasarkan

Pendidikan di Klinik

Mawar

RSUD

Kabupaten

Indramayu

2018

\begin{tabular}{rlcc}
\hline Variabel & Kategori & F & \% \\
\hline Pendidikan & SD & 149 & 79 \\
\cline { 2 - 4 } & SMP & 39 & 21 \\
\hline Jumlah & & 188 & 100 \\
\hline
\end{tabular}

Berdasarkan tabel 3 di atas menunjukan bahwa sebanyak 149 Responden

(79\%)

tingkat pendidikannya adalah SD.

d. Jenis Pekerjaan

Tabel 4 Distribusi

Responden

Berdasarkan

Pekerjaan di Klinik

Mawar

Kabupaten

Indramayu Tahun

2018

\begin{tabular}{llcc}
\hline Pekerjaan & Nelayan & 7 & 4 \\
\cline { 2 - 4 } & Petani & 16 & 9 \\
\cline { 2 - 4 } & Wiraswasta & 70 & 37 \\
& & & \\
\cline { 2 - 4 } & $\begin{array}{l}\text { Tidak } \\
\text { bekerja }\end{array}$ & 29 & 15 \\
\cline { 2 - 4 } & Lain - lain & 66 & 35 \\
\hline Jumlah & & 188 & 100 \\
\hline
\end{tabular}

Berdasarkan tabel 4 di atas menunjukan bahwa sebanyak 70 responden $(37,0)$ bekerja sebagai wiraswasta.

2. Analisa Univariat

Tabel 5 Distribusi

Frekuensi Gambaran

Konsep Diri pada

ODHA di Klinik

Mawar RSUD

Kabupaten

Indramayu Tahun

2018

\begin{tabular}{lrc}
\hline Kategori & F & \% \\
\hline Positif & 113 & 53 \\
\cline { 2 - 3 } Negatif & 75 & 47 \\
\hline Jumlah & $\mathbf{1 8 8}$ & $\mathbf{1 0 0}$ \\
\hline
\end{tabular}

Berdasarkan tabel 5 diatas menunjukan 
Bestina Nindy Virgiani: Konsep Diri (ODHA)

bahwa sebanyak 99 responden

$(53 \%)$

memiliki Konsep Diri positif.

Tabel 6 Distribusi

Frekuensi Gambaran Konsep

Diri

berdasarkan

Citra

Tubuh, Ideal Diri,

Harga Diri, Penampilan

Peran dan Identitas

Diri pada ODHA di

Klinik Mawar RSUD

Kabupaten Indramayu

Tahun 2018

\begin{tabular}{cccc}
\hline \hline Variabel & Kategori & $\mathbf{F}$ & $\mathbf{\%}$ \\
\hline Citra Tubuh & Positif & 98 & 52 \\
& Negatif & 90 & 48 \\
\cline { 2 - 4 } Ideal Diri & Jumlah & 188 & 100 \\
& Positif & 116 & 62 \\
& Negatif & 72 & 38 \\
\cline { 2 - 4 } & Jumlah & 188 & 100 \\
\hline Harga Diri & Positif & 92 & 49 \\
& Negatif & 96 & 51 \\
\cline { 2 - 4 } & Jumlah & 188 & 100 \\
\hline Penampilan & Positif & 31 & 16 \\
peran & Negatif & 167 & 84 \\
\cline { 2 - 4 } & Jumlah & 188 & 100 \\
\hline Identitas & Positif & 98 & 52 \\
Diri & Negatif & 90 & 48 \\
\cline { 2 - 4 } & Jumlah & 188 & 100 \\
\hline \hline
\end{tabular}

Berdasarkan tabel 6 distribusi frekuensi konsep diri berdasarkan citra tubuh pada 98 responden

$(52 \%)$

memiliki konsep diri positif, berdasarkan Ideal Diri sebanyak 116 responden memiliki konsep diri positif, berdasarkan Harga Diri sebanyak 96 responden

(51\%) memiliki konsep diri negatif, berdasarkan Penampilan Peran sebanyak 167 responden memiliki konsep diri negatif, berdasarkan Identitas Diri sebanyak 98 responden (52\%) memiliki konsep diri positif.

\section{Pembahasan}

Berdasarkan hasil penelitian menunjukan bahwa konsep diri orang dengan gangguan HIV AIDS (ODHA) positif dengan hasil penelitian sebanyak 99 responden (52,7\%). Hasil penelitian ini juga sejalan dengan hasil penelitian yang dilakukan oleh 
Aritonang (2014) di kelurahan kebon pisang kecamatan sumur Bandung kota Bandung tentang konsep diri orang dengan gangguan HIV AIDS menunjukan kesemua aspek ini tercemin secara positif pada diri informan dan pada akhirnya informan memiliki konsep diri yang positif terhadap dirinya.

Menurut amaliah (2016) Faktor yang mempengaruhi konsep diri yaitu faktor internal dan faktor eksternal. Faktor internal meliputi intelegensi, motivasi, emosi, kompetensi personal, episode keberhasilan dan kegagalan, status kesehatan, usia, persepsi, penampilan fisik, jenis kelamin, aktualisasi diri, stress. Sedangkan faktor eksternal meliputi orang tua, keluarga, teman sebaya, peran pendidik, kebudayaan, status sosial, pengalaman interpersonal.

\section{Citra tubuh Orang Dengan Gangguan HIV AIDS (ODHA)}

Berdasarkan hasil penelitian menunjukan bahwa citra tubuh orang dengan gangguan HIV AIDS (ODHA) positiv dengan hasil penelitian sebanyak 98 responden (52,1\%). Hasil penelitian ini sejalan dengan hasil penelitian

Rohmat (2011) mengenai Gambaran Konsep Diri Pada Orang dengan HIV AIDS di Rumah Sakit GRHASIA

mengungkapkan hasil wawancara dari 3 responden ODHA mempunyai cintra tubuh yang positif.

Citra tubuh harus realistis karena semakin seseorang dapat menerima dan menyukai tubuhnya ia akan lebih bebas dan merasa aman dari kecemasan sehingga harga dirinya akan meningkat. Pada penelitian ini ODHA memiliki citra tubuh yang positif, hal ini 
disebabkan

karena orang dengan HIV AIDS telah menerima perubahan pada diri setelah terinfeksi HIV. Sikap individu terhadap tubuhnya

mencerminkan aspek penting dalam dirinya misalnya perasaan menarik atau tidak, gemuk atau tidak, dan sebagainya (Fitryasari, 2015).

\section{Ideal Diri Orang Dengan Gangguan HIV AIDS (ODHA)}

Berdasarkan hasil penelitian menunjukan bahwa ideal diri orang dengan gangguan HIV AIDS (ODHA) positif dengan hasil penelitian sebanyak 116 responden (61,7\%). Hasil penelitian ini sejalan dengan hasil penelitian Rohmat (2011) mengenai Gambaran Konsep Diri Pada Orang dengan HIV AIDS di Rumah Sakit GRHASIA mengungkapkan hasil wawancara dari 3 responden ODHA mempunyai ideal diri yang positif.

Ideal diri bisa bersifat realistis, bisa juga tidak. Saat ideal diri seseorang mendekati persepsinya tentang diri sendiri, orang tersebut cenderung tidak ingin berubah dari kondisinya saat ini. Sebaliknya, jika ideal diri tersebut tidak sesuai dengan persepsi tentang diri sendiri, orang tersebut akan terpacu untuk memperbaiki dirinya. Tetapi ingat, jika ideal diri terlalu tinggi justru dapat menyebabkan harga diri rendah.

ODHA memiliki ideal diri tubuh yang positif, hal ini disebabkan karena ideal diri adalah suatu tujuan yang ingin dicapai oleh setiap orang, begitupun orang dengan HIV AIDS selalu berkeinginan untuk sembuh dan hidup seperti manusia pada umumnya, hal ini lah yang dapat menjadikan orang dengan HIV AIDS 
mempunyai ideal diri yang positif.

\section{Harga Diri Orang Dengan Gangguan HIV AIDS (ODHA)}

Berdasarkan hasil penelitian menunjukan bahwa harga diri orang dengan gangguan HIV AIDS (ODHA) positiv dengan hasil penelitian sebanyak 96 responden (51,1\%). Hasil penelitian ini sejalan dengan hasil penelitian wahyu (2012) mengenai Konsep Diri Dan Masalah Yang di Alami Orang dengan HIV AIDS mempunyai ideal diri yang negatif.

ODHA memiliki harga diri yang negatif, hal ini disebabkan karena orang dengan HIV AIDS cenderung menilai dirinya buruk bahwa dirinya mempunyai penyakit yang stigmanya buruk dimasyarakat dan mengkritik diri sendiri maupun merasa rendah dimata masyarakat.

\section{Penampilan Peran Orang Dengan Gangguan HIV AIDS (ODHA)}

Berdasarkan hasil penelitian menunjukan bahwa peran orang dengan gangguan HIV AIDS (ODHA) negatif dengan hasil penelitian sebanyak 167 responden $(83,5 \%)$. Hasil penelitian ini sejalan dengan hasil penelitian wahyu (2012) mengenai Konsep Diri Dan Masalah Yang di Alami Orang dengan HIV AIDS mempunyai ideal diri yang negatif.

Hasil penelitian ini menunjukan bahwa pada ODHA memiliki harga diri yang positif, hal ini disebabkan karena orang dengan HIV AIDS juga masih merasa berguna baik untuk dirinya sendiri, kelurganya maupun masyarakat. Hal ini bisa dilihat dari jawaban responden yang menjawab tidak merasa perannya terganggu sebagai orang tua/anak 
semenjak menderita HIV AIDS.

\section{Identitas diri Orang Dengan Gangguan HIV AIDS (ODHA).}

Berdasarkan hasil penelitian menunjukan bahwa identitas diri orang dengan gangguan HIV AIDS (ODHA) positiv dengan hasil penelitian sebanyak 98 responden (52,1\%). Hasil penelitian ini sejalan dengan hasil penelitian (2011)

Rohmat Gambaran Konsep Diri Gambaran Konsep Diri Pada Orang dengan HIV AIDS di Rumah Sakit GRHASIA

mengungkapkan hasil wawancara dari 3 responden ODHA mempunyai peran yang positif.

Hasil penelitian ini menunjukan bahwa pada ODHA memiliki identintitas diri yang positif, hal ini disebabkan karena orang dengan HIV AIDS sudah menerima dengan keadaannya sebagai ODHA dan adanya tidak adanya penolakan baik dari kelurga maupun masyarakat sekitar tempat tinggalnya.

\section{Simpulan}

Berdasarkan

hasil penelitian menunjukan bahwa:

1. Konsep diri orang dengan gangguan HIV AIDS (ODHA) positif dengan hasil penelitian sebanyak 99 responden (52,7\%).

2. Citra tubuh orang dengan gangguan HIV AIDS (ODHA) positif dengan hasil penelitian sebanyak 98 responden (52, $1 \%)$.

3. Ideal diri orang dengan gangguan HIV AIDS (ODHA) positiv dengan hasil penelitian sebanyak 116 responden $(61,7 \%)$.

4. Harga diri orang dengan gangguan HIV AIDS (ODHA) positiv dengan hasil penelitian sebanyak 96 responden (51,1\%).

5. Peran orang dengan gangguan HIV AIDS 


$\begin{array}{lr}\text { (ODHA) } & \text { negatif } \\ \text { dengan } & \text { hasil } \\ \text { penelitian } & \text { sebanyak } \\ 89 & \text { responden } \\ (56,7 \%) . & \\ \text { 6. } & \text { Identitas diri orang } \\ \text { dengan gangguan } \\ \text { HIV AIDS (ODHA) } \\ \text { positif dengan hasil } \\ \text { penelitian sebanyak } \\ 98 \quad \text { responden } \\ (52,1 \%) .\end{array}$

\section{Daftar Pustaka}

Dewa Putu Yudi Pardita. 2014.

Dampak

Ekonomi, Analisis

Psikologi Penderita HIV/AIDS Di Kota Denpasar, Tesis: Program

Pascasarjana

Universitas

Udayana, Denpasar.

Dirjen Yan Med. 2013. Modul Pelatihan Konseling dan tes HIV Sukarela (VCT), Jakarta: Kemkes RI. Djuanda, Adhi. 2009. Ilmu Penyakit Kulit dan Kelamin, Jakarta,FKUI Ghufron, M. N. \& S. Risnawati Rini.
2011. Teori-Teori Psikologi. Jogjakarta:Arruzz media Pusat Data Dan Informasi Kemenkes RI. 2014. Situasi Dan Analisis HIV AIDS, Jakarta: Ditjen PP dan PL Kemekes RI.

Kemenkes RI. 2017.

Pusat Data Dan Informasi Kementrian Kesehatan

$R I$. Jakarta: Pusdatin Kemenkes RI.

Notoatmodjo. 2012. Metode Penelitian Kesehatan edisi Revisi. Jakarta: Rineka Cipta.

Pardita, D. P. 2014. Analisis Dampak Sosial, Ekonomi dan Psikologis Penderita HIV/AIDS di Kota Denpasar. Tesis. (Tidak Diterbitkan). Denpasar : Program Pascasarjana Universitas Udayana.

Rohmat. M. S. 2011. Konsep Diri Pada Orang Deangan HIV AIDS di Rumah Sakit GRHASIA 
Bestina Nindy Virgiani: Konsep Diri (ODHA)

Provinsi Daerah

Istimewa

Yogyakarta. Sekolah

Tinggi

Ilmu

Kesehatan 'Aisyiyah

Yogyakarta.

Wahyu,

S,.Taufik;

Asmidirllyas. 2012.

Konsep Diri dan

Masalah yang

Dialami Orang Terin

feksi

HIV/AIDS.

Junal Ilmiah Konseling,

1, 1-12.

Andreas Dwi Atmoko;Zainal

Munir;Gilang

Ramadhan.

(2019).

PENGARUH

MENONTON

TAYANGAN

TELEVISI TERHADAP

PERILAKU AGRESIF

PADA

ANAK

PRASEKOLAH

Andreas. Keperawatan

Profesional, 7(1).

Retrieved from

https://ejournal.unuja.ac.i

$\mathrm{d} / \mathrm{index}$.php/jkp/index $\% 0$

APENGARUH

Kholisotin. (2017). The

Effectiveness

of

Preclampsia Educational

Package To The

Knowledge, Attitude,

And Skill of Pregnant

Women At Risk of
Preeclampsia.

Universitas

Muhammadiyah Jakarta.

Munir, Z. (2017). Analisis pengaruh Pendidikan,

Pendapatan dan

Pekerjaan terhadap

Motivasi Orangtua

dalam Kualitas

Perawatan Anak dengan

HIV/AIDS. Universitas

Muhammadiyah Jakarta.

Munir, Z., \& Romadhoni, F. (2019). PENGARUH PENDIDIKAN DAN PEKERJAAN

ORANGTUA DENGAN TINGKAT

KEPATUHAN ARV

PADA ANAK HIV /

AIDS. Jurnal Ilmiah

STIKES Citra Delima

Bangka Belitung, 2, 131135.

Zainal Munir; Yulisyowati;

Virana.

(2019).

Hubungan Pola Asuh

Orang Tua dalam

Menstimulasi

Perkembangan Motorik

Kasar dan Halus Usia

Pra Sekolah. Jurnal

Keperawatan

Profesional, 7(Pediatric),

55-71. Retrieved from https://ejournal.unuja.ac.i d/index.php/jkp/index 
Bestina Nindy Virgiani: Konsep Diri (ODHA) 